\title{
The Religiosity Dimension and Resilience of Teachers of Students with Dissabilities at Special Schools in Sleman, Yogyakarta
}

\author{
$1^{\text {st }}$ Halimatus Sakdiyah \\ Departmen of Psychology \\ UIN Sunan Kalijaga \\ Yogyakarta, Indonesia \\ alisyabaqina@gmail.com
}

\author{
$2^{\text {nd }}$ Erika Setyanti Kusumaputri* \\ Departmen of Psychology \\ UIN Sunan Kalijaga \\ Yogyakarta, Indonesia \\ erika.kusumaputri@uin-suka.ac.id
}

\begin{abstract}
This study aims to examine the contributions of seven religiosity dimensions toward the resilience of disability teachers at SLB in Sleman, Yogyakarta. This research uses quantitative method for analyzing the data. In collecting data, Resilience and Religiosity Scale is used as the instrument. The subjects of this study are 205 disability teachers who come from 18 SLB in Sleman Regency, Yogyakarta. This study used Cluster Random Sampling method. According to the study result analysis by using analysis of multiple regression technique, it shows that there are only three religiosity dimensions that have a significant influence toward resilience of disability students in Sleman Regency, Yogyakarta. Those three dimensions are: (1) Forgiveness, which has value $p=0,003(p<0,05)$ and the amount of contribution toward the resilience is $8,5 \%$; (2) Thankfulness, which has value $p=0,000$ $(p<0,05)$ and the amount of contribution was $36 \%$; and $(3)$ God as Judge has value $p=0,032 \quad(p<0,05)$ and the amount of contribution toward the resilience was $1,6 \%$. The other four dimensions of religiousity which are not have relation toward the resilience are general religiosity, social religiosity, involved God, and un-vengefulness.
\end{abstract}

Keywords-resilience, religious dimensions, disability student, and special school.

\section{INTRODUCTION}

Each organization has their own goals and challenges. The typical challenges that organization face is, among others, increased stress, workload, limited budget, and changing requests. However, a good organization would continue to adapt to global competition, rapid social and technological changes, as well as environmental climate [1].

One of the solutions to deal and reduce these organizational challenges is by managing employees' resilience. According to Reivich \& Shatte [2], resilience is the ability to persevere and adapt when faced with obstacles. Resilience is considered the key to successful work-life and achieving satisfaction in life.

Resilience at work has the benefit of transforming threats (i.e., risks, uncertainties regarding a global resource, technological changes, reduced workforce, physical fatigue, stress, and emotion) to be used a chance for growth [3]. Employees with a high level of resilience are trusted to work in any environment and have their way of completing the given task [4].

Creating resilience at work can be started from the managerial level, by merely having them distribute task according to the skills and knowledge of the employee that would not burden them [5].

Several factors characterize resilient individuals: emotion regulation, impulse control, empathy, optimism, causal analysis, self-efficacy, and reaching out. These individual characteristics by Reivich \& Shatte [2] are also used to describe the aspects of resilience. Resilience could only be developed when a person truly experienced a setback and obstacle at work [1].

Resilience is influenced by both internal and external factors that show the strength and perseverance of a person to bounce back from a negative experience that significantly hampers their life. Meanwhile, Pargament and Cummings argued that one of the most significant factors for resilience is religiosity [6]. Kendler et al., [7] facilitate the understanding of diversity by dividing the construct of diversity into several dimensions of measurement.

\section{METHODS}

This quantitative study used a correlational study design. The population of this study was educators of children with special needs in SLB Sleman, Yogyakarta. The sampling technique in this study uses cluster sampling. The number of subjects in this study was 205 educators of children with special needs.

This study used a Likert scale as a data collection instrument. The resilience scale was constructed by the current researcher based on Reivich \& Shatte's resilience aspects [2]. Those aspects are emotional regulation, impulse control, empathy, optimism, causal analysis, self-efficacy, and reaching out.

The religiosity scale of this study is also constructed by the current researcher based on Kendler's religiosity dimensions [8]. The dimensions are General Religiosity, Social Religiosity, God's Involvement, 
Forgiveness, God as Judge, Un-revengefulness, Thankfulness.

\section{RESULT}

The hypotheses that were accepted were Thankfulness, Forgiveness, and God as Judge. This finding is derived from comparing the score with the standard score of $\mathrm{p}=<0.05$ and $\mathrm{t}=>1.988$. Thankfulness achieved a score of $\mathrm{p}<0.05$ and $\mathrm{t}=$ $4.47(\mathrm{t}>1.988)$. Forgiveness has a score of $\mathrm{p}=0.003(\mathrm{p}<0.05)$ and $\mathrm{t}=4.440(\mathrm{t}>1.988)$. God as Judge achieved a score of $\mathrm{p}=0.003(\mathrm{p}<0.05)$ and $\mathrm{t}=2.261(\mathrm{t}>1.988)$. The remaining four independent variables (i.e., General religiosity, Social Religiosity,

Un-rrevengefulness and God's involvement have a $\mathrm{p}>0.05$ and $\mathrm{t}<1.988$, indicating that both dimensions do not have a significant relationship with the dependent variable. Thankfulness contributes $36 \%$ to explaining resilience, depicted by the $\mathrm{R}$ Square score of 0.360. Forgiveness contributes $8.5 \%$ to resilience ( $\mathrm{R}$ Square $=0.085$ ), while God as Judge contributes $1.6 \%$ in explaining resilience ( $\mathrm{R}$ Square $=0.016)$. The remaining $53.9 \%$ is explained by other variables outside the scope of this study.

\section{DISCUSSION}

The finding of this study shows that there is a positive relationship between employees' religiosity and resilience. A person to be religious does not have to include seven dimensions. Kendler divides religiosity into seven dimensions. Each dimensions in this research looks at how much contribution to resilience. A person who only include or implement in their live on several dimensions can already be said religiously by Kendler [7]. The independent variable of this study was divided into seven sub-variables consisting of Kendler's religiosity dimensions. These independent variables (i.e., General Religiosity, Social Religiosity, Involved God, Forgiveness, God as Judge, Unrevengefulness, Thankfulness) influence the dependent variable, namely resilience. Each of the variables was measured and analyzed to determine the strength of their influence toward resilience. This study has a total of 205 educators of children with special needs who permanently work at a Special Education School as respondents. The sample was collected through the Cluster Random Sampling method.

This current study has seven hypotheses to investigate the contribution of each dimension proposed by Kendler (2003). Based on the findings, three hypotheses were accepted, while four others were rejected. The hypotheses that were accepted were those depicting the influence of the Thankfulness, Forgiveness, and God as Judge dimension based on their statistical results. Thankfulness achieved an Adjusted $\mathrm{R}$ Square score of 0.360 , indicating that it contributes $36 \%$ to explaining resilience. This dimension describes how individuals were found to be relatively grateful. Grateful individuals are those who express their thankfulness to God and show no resentment to Him for the life that they have [7]. Gratitude can help a person increase their ability to face obstacles and find solutions [8].

Next, Forgiveness achieved a score of $0.445(\mathrm{p}<0.05)$, which is below the score of Thankfulness. This result shows that $0.45-0.360=0.085$, indicating that Forgiveness contributes $8.5 \%$ to explaining resilience. This result is in line with a study by Habibi \& Hidayati (2017), who claimed that there is a positive relationship between Forgiveness - be it for self or others - on resilience. Forgiveness aids people in facing difficult situations because it opens up one's faith [9].

Meanwhile, God as Judge significantly contributes $1.6 \%$ to influencing resilience. However, the relationship is negative. In other words, the more that someone believes God as Judge, the smaller one's resilience becomes and vice versa. This is because God as Judge dimension represents a passive behavior, while resilience is an active process where someone tries to survive from the obstacles they face [1]

Educators who believe in God as Judge tend to have a positive mindset and surrender in the process because God has already determined each job. This is because humans believe that God is considered authoritative. A surrendering behavior tends to represent a passive behavior despite it being perceived positively. It is perceived positively because the motivation behind a person surrendering comes from a calm and firm belief that God holds everyone's fate. For that reason, the more people believe in God as Judge, the less resilient behavior they exhibit, vice versa.

According to the findings, the remaining dimensions did not have a significant relationship with resilience, so the strength of the relationship with the latter could not be determined. The dimensions that have no significant relationship with resilience are General Religiosity $(\mathrm{p}=$ $0.444)$, Social Religiosity $(\mathrm{p}=0.237)$, Involved God ( $\mathrm{p}=$ $0.218)$, and Un-revengefulness $(\mathrm{p}=0.237)$. Considering that the remaining four dimensions have a significance score above 0.05 , the hypotheses are therefore rejected.

The findings of this study are in line with Lucia \& Kurniawa (2017), who explained that their study proved that there is a positive correlation between employees' religiosity and resilience [10]. Additionally, Rahmawati (2013) also exclaimed that religiosity has a significant effect on resilience [11]. In other words, the higher employees' religiosity is, the more resilience they exhibit and vice versa. Kendler (2003) explained that someone could be considered religious without having to exhibit all seven dimensions. Someone with one or two substantial dimensions could still influence the emergence of the other dimensions [7].

This study has several limitations. Current studies regarding educators of students with special needs in Special Education Schools are still limited, affecting the depth of the analysis that the current researcher could explore. Next, the distance between one school to the next was quite far. Thus, data collection would not be simultaneously conducted at the same time.

Based on the above limitations, future studies are advised to learn from it and use other theories or media. The current researcher acknowledges that there are still various other factors that could influence resilience. The limitations of this study are expected to inform future studies on the development of further themes for research on resilience as well as application in the field of Education for Children with Special Needs.

\section{CONCLUSION}

Based on the findings of this research, it can be concluded that three dimensions significantly relates to resilience, namely Thankfulness, Forgiveness, and God as 
Judge. The remaining dimensions (i.e., General Religiosity, Social Religiosity, Involved God, Un-revengefulness) have no positive relationship with the dependent variable; Thus, its hypotheses were rejected. The contribution of the previous four dimensions of resilience could not be predicted because it has no significant relationship with resilience. The total contribution of the religiosity dimension toward resilience is $40.1 \%$. Thus, the remaining $59.9 \%$ is influenced by other variables outside of the scope of this study.

Future studies are advised to increase the number of participants to allow the generalizability of the research findings. Resilience can be increased by increasing thankfulness, forgiveness, and believing in God's destiny. Whereas for agencies that shelter children with special needs, child educators should be directed to pay more attention to the dimensions of their religiosity to be able to maintain their resilience.

\section{ACKNOWLEDGMENT}

Researcher thank to the faculty of Social Sciences and Humanities UIN Sunan Kalijaga, majoring in psychology, all of agencies used for data collection and all colleagues involved in this research.

\section{REFERENCES}

[1] McEwen, K. (2011). Building Resilience at Work. Australia: Autralian Academic Press.
[2] Reivich, K. \& Shatte, A. (2002). The Resilience Factor: 7 Essential Skills For Overcoming Life's Inevitable Obstacles. Newyork: Broadway Book.

[3] Liwarto, I. H., \& Kurniawan, A. (2015). Hubungan psycap dengan kinerja karyawan PT. X Bandung. Jurnal Manajemen, 14(2), 223244.

[4] Astika, N. F.L. \& Saptoto, R. 2016. Peran Resiliensi dan Iklim Organisasi terhadap Work Engagement. Gadjah Mada Journal of Psychology. Vol. 2, No. 1. 38-47: 2407-7798

[5] Malik, A. (2013). Efficacy, Hope, Optimism and Resilience at Workplace Positive Organizational Behavior. International Journal of Scientific and Research Publications. Vol. 3.

[6] Reich, J. W., Zautra, A. J., Hall. J. S. (2010). Handbook Of Adult Resilience. The Guildford Press: New York

[7] Kendler, K. S., dkk. (2003). Dimension Of Religiosity and Their Relationship to Lifetime Psychiatric and Substance Use Disorder. American Journal of Psychiatry. 160-503.

[8] Utami, N. M., dkk. (2018). Hubungan Rasa Syukur dengan Resiliensi Pengungsian Gunung Agung di Kabupate Karangasem. Ejournal likmbali. Institute Ilmu Kesehatan Medika Persada.

[9] Habibi, M, M. \& Hidayati, F. (2017). Hubungan Antara Pemaafan Diri Sendiri, Pemaafan Orang Lain dan Pemaafan Situasi dengan Resiliensi pada Mahasiswa Baru (Studi Korelasi Pada Mahasiswa Baru Universitas Diponegoro Semarang). Jurnal Empati. Vol. 6. 2. 62-69.

[10] Lucia, R., \& Kurniawan, J., E., (2017). Hubungan antara Regiliusitas dan Resiliensi pada Karyawan. Psychopreneur Journal. 1(2): 126-136

[11] Rahmawati, Sri W. 2014. Role of Religiousness/Spirituality in Resilience of Fisheries College Cadets. Journal of Educational, Health and Community Psychology. Vol. 3, No. 1. 